\title{
Dayasaing Komoditas Bawang Merah di Kabupaten Majalengka, Jawa Barat
}

\author{
Competitiveness of Shallot Commodity in the District of Majalengka, West Java
}

\author{
Lola Rahmadona $^{*}$, Anna Fariyanti ${ }^{2}$, dan Burhanuddin ${ }^{2}$
}

Diterima 30 Agustus 2016/Disetujui 10 Juli 2017

\begin{abstract}
Shallot is included in the category of high value commodities, so that many farmers cultivate it. Indonesia still remains as net importer of shallot. The objectives of this study were to analyze the competitiveness of shallot farming in the district of Majalengka. Respondents were 37 farmers selected by using purposive sampling technique. The data were analyzed by the method of the Policy Analysis Matrix (PAM) to determine the level of profit and competitiveness. The result showed that shallot farming in the district of Majalengka was financially profitable, but economically unprofitable. The analysis of the competitiveness in the district of Majalengka showed the shallot farming have no competitiveness.
\end{abstract}

Keywords: competitiveness, Policy Analysis Matrix, shallot farming

\begin{abstract}
ABSTRAK
Bawang merah termasuk dalam kategori komoditas bernilai tinggi, sehingga banyak petani yang mengusahakannya. Namun demikian Indonesia masih tetap sebagai net importir bawang merah. Tujuan dari penelitian ini ialah untuk menganalisis dayasaing komoditas bawang merah di Kabupaten Majalengka. Responden 37 petani yang dipilih dengan menggunakan teknik purposive sampling. Data dianalisis dengan menggunakan metode Policy Analysis Matrix (PAM). Hasil penelitian menunjukkan bahwa komoditas bawang merah di Kabupaten Majalengka menguntungkan secara finansial tetapi secara ekonomi tidak menguntungkan. Analisis dayasaing di Kabupaten Majalengka menunjukkan komoditas bawang merah tidak memiliki dayasaing.
\end{abstract}

Kata kunci: dayasaing, Policy Analysis Matrix, usahatani bawang merah

\section{PENDAHULUAN}

Bawang Merah merupakan salah satu komoditas strategis di Indonesia, karena perubahan terhadap harga dari bawang merah dapat mempengaruhi inflasi. Penyebab inflasi yang tinggi dapat disebabkan adanya kenaikan harga bawang merah. Menurut data inflasi dari BPS pada tahun 2010-2014 inflasi tertinggi terjadi pada tahun 2013 yaitu terjadi pada bulan Juli. Bawang merah menyumbang sebesar 0.48 persen terhadap inflasi pada bulan Juli 2013 (BPS, 2014). Selain itu, bawang merah juga merupakan salah satu komoditas bernilai tinggi (high value comodity) sehingga banyak petani yang mengusahakannya. Total jumlah produksi bawang merah di Indonesia pada tahun 2013 mencapai 1.01 juta ton dan mengalami peningkatan pada tahun 2014 sebesar 1.23 juta ton atau sebesar 21.48 persen. Meskipun Indonesia mampu untuk memproduksi bawang merah sendiri, sampai saat ini Indonesia masih menjadi pengimpor (net importer) bawang merah. Pada tahun 2014, volume impor bawang merah mencapai 74903 ton, sedangkan volume ekspornya hanya 4439 ton (Kementan, 2015). Masih tingginya volume impor bawang merah ini disebabkan oleh rendahnya produktivitas di bawah potensial, produksi yang masih bersifat musiman dan tingginya biaya produksi.

${ }^{1}$ Program Pascasarjana Program Studi Agribisnis, Institut Pertanian Bogor Gedung FEM Lt. 3, Jl. Kamper Kampus IPB Dramaga Bogor 16680

${ }^{2}$ Departemen Agribisnis, Fakultas Ekonomi dan Manajemen, Institut Pertanian Bogor

Jl. Kamper Wing 2 Level 3 Kampus IPB Dramaga Bogor 16680.

email: lolarahmadona91@ gmail.com (*penulis korespondensi) 
Pusat penghasil bawang merah di Indonesia tersebar di 10 provinsi diantaranya Jawa Tengah, Jawa Timur, Jawa Barat, Nusa Tenggara Barat, D. I. Yogyakarta, Sumatera Barat, Sumatera Utara, Sulawesi Selatan, Bali dan Nusa Tenggara Timur. Provinsi-provinsi ini menyumbang 87.16 persen produksi total bawang merah di Indonesia pada tahun 2014. Sebesar 78.46 persen produksi disumbang oleh provinsi-provinsi yang ada di Pulau Jawa (Kementerian Pertanian, 2015). Provinsi Jawa Barat merupakan salah satu provinsi penghasil utama bawang merah dengan pusat penghasil tersebar di empat wilayah sentra yaitu Kabupaten Cirebon, Kabupaten Bandung, Kabupaten Majalengka dan Kabupaten Garut. Diantara ke empat Kabupaten Sentra ini, Kabupaten Majalengka merupakan kabupaten yang memiliki tingkat produktivitas yang meningkat setiap tahunnya dengan rata-rata peningkatan produktivitas di Kabupaten Majalengka sebesar 7.38 persen. Menurut Kennedy et al. (1998) peningkatan produktivitas merupakan salah satu kunci utama dalam persaingan, karena dengan produktivitas yang tinggi diharapkan proses produksi menjadi lebih efisien dan dapat memberikan harga yang lebih kompetitif. Lebih lanjut menurut teori dari Ricardo pada tahun 1817, keunggulan produktivitas bukanlah satusatunya faktor untuk memenangkan persaingan tetapi terdapat beberapa faktor lain yang menyebabkan sebuah negara dapat bersaing tetapi juga faktor biaya-biaya input yang rendah. Hal ini memberikan gambaran bahwa terdapat potensi yang cukup besar dalam usaha tani bawang merah di Kabupaten Majalengka. Meskipun menurut produktivitas bawang merah di Kabupaten Majalengka berpotensi cukup besar namun angka produktivitas tersebut masih di bawah produktivitas potensial yaitu sebesar 20 ton $\mathrm{ha}^{-1}$. Hal ini disebabkan oleh pengelolaan usahatani bawang merah secara baik belum sepenuhnya dilakukan oleh petani, karena masih adanya permasalahan yang saat ini dihadapi oleh petani bawang merah di Kabupaten Majalengka. Permasalahan yang dihadapi petani bawang merah di Kabupaten Majalengka ialah produksi bawang merah yang bersifat musiman, tingginya biaya produksi, dan fluktuasi harga bawang merah.

Ketersediaan bawang merah yang tidak merata di pasaran disebabkan oleh produksi bawang merah yang bersifat musiman. Di Kabupaten Majalengka pada umumnya musim tanam bawang merah (in season) dilakukan di musim kemarau pada bulan Februari sampai dengan bulan September (Apriani, 2011; Rachman et al., 2004). Pada musim hujan petani jarang sekali melakukan penanaman bawang merah yaitu pada bulan OktoberJanuari. Menurut Rachman et al. (2004), petani bawang merah di Kabupaten Majalengka tidak melakukan penanaman pada musim hujan dikarenakan pengaruh curah hujan yang tinggi akan menyebabkan terjadinya kerusakan fisik pada daun bawang merah dan busuk umbi. Hal ini akan memberikan dampak terhadap kehilangan hasil panen pada musim hujan. Oleh sebab itu, penanaman bawang merah lebih banyak dilakukan pada musim kemarau. Musim kemarau air sering merupakan faktor pembatas bagi pertumbuhan tanaman, terutama di daerah kering. Penanaman bawang merah di musim kemarau dibantu dengan irigasi dapat dengan frekuensi dua kali sehari dapat meningkatkan bobot panen bawang merah. (Fauziah et al., 2016) Usahatani bawang merah membutuhkan biaya per satuan luas lahan yang lebih tinggi khususnya untuk upah tenaga kerja dan sarana produksi. Menurut Rachman et al. (2004) di Kabupaten Majalengka pengeluaran biaya untuk sarana produksi menempati urutan pertama dengan proporsi biaya berkisar antara 21.60-34.50 persen dibandingkan biaya untuk penggunaan tenaga kerja sebesar 16.3-32.9 persen terhadap total penerimaan. Tingginya biaya sarana produksi, terutama disebabkan oleh tingginya harga bibit. Rata-rata biaya produksi yang dikeluarkan oleh petani bawang merah di Kabupaten Majalengka sebesar 10 $710.53 \mathrm{~kg}^{-1}$ (Apriani, 2011).

Permasalahan yang menjadi bagian dari kompleksitas usahatani bawang merah adalah harga jual bawang merah yang berfluktuasi, bahkan harga akan turun pada saat panen raya dan masuknya bawang merah impor. Fluktuasi harga bawang merah tergantung dengan kondisi pasar yaitu terhadap jumlah permintaan dan penawaran bawang merah. Perubahan harga tertinggi terjadi pada tahun 2013 yaitu pada bulan Agustus. Harga eceran bawang merah pada bulan Agustus 2013 melonjak tinggi menjadi Rp $60549 \mathrm{~kg}^{-1}$ dari Rp $29459 \mathrm{~kg}^{-1}$ pada bulan Juni 2013. Tingginya harga eceran bawang merah ini 
dikarenakan terjadinya peningkatan permintaan pada bulan Ramadhan dan hari raya Idul Fitri.

Berdasarkan uraian tersebut, apabila permasalahan tersebut tidak dapat dikelola dengan baik, maka pasar akan dikuasai oleh produk impor. Volume impor bawang merah setiap tahunnya selalu lebih besar dibandingkan volume ekspornya. Kenyataan ini memberikan dampak negatif bagi petani, karena dengan masuknya bawang merah impor akan menjatuhkan harga bawang merah lokal sehingga petani dapat dirugikan. Berdasarkan rumusan permasalahan yang telah dijelaskan di atas, tujuan penelitian ini ialah: (1) menganalisis keuntungan privat dan sosial usahatani bawang merah di Kabupaten Majalengka, dan (2) menganalisis dayasaing bawang merah di Kabupaten Majalengka

\section{METODE PENELITIAN}

\section{Lokasi dan Waktu Penelitian}

Penelitian dilakukan di Kabupaten Majalengka, Provinsi Jawa Barat. Pemilihan lokasi dilakukan secara purposive sampling dengan mempertimbangkan daerah tersebut mempunyai potensi dalam pengusahaan bawang merah. Kabupaten Majalengka terpilih sebagai daerah yang mempunyai potensi pengembangan kawasan tanaman hortikultura bawang merah (Deptan Jawa Barat, 2015). Penelitian ini dilaksanakan pada bulan September 2015 sampai April 2016.

\section{Jenis dan Sumber Data}

Data yang digunakan dalam penelitian ini merupakan data sekunder yang diperoleh dari data penelitian komoditas bawang merah Pusat Kajian Hortikultura Tropika (PKHT) IPB tahun 2015. Responden petani bawang merah ditentukan secara purposive. Jumlah data responden yang digunakan dalam penelitian ini sebanyak 37 petani bawang merah di Kabupaten Majalengka. Selain itu, data pendukung lainnya diperoleh melalui studi literatur dan pustaka yang relevan dengan topik yang diteliti.

\section{Metode Pengolahan dan Analisis Data}

Metode analisis yang sesuai untuk menjawab tujuan kajian ialah Policy Analysis
Matrix (PAM). Melalui matriks PAM dapat diketahui tingkat keuntungan usahatani bawang merah secara finansial dan ekonomi. Keuntungan finansial merupakan selisih antara penerimaan dengan biaya tradable maupun non tradable yang diukur dengan menggunakan harga privat atau harga aktual, sedangkan keuntungan ekonomi adalah keuntungan yang dihitung berdasarkan harga sosial atau bayangan. Nilai keuntungan privat yang lebih besar dari nol berarti secara finansial komoditas tersebut layak untuk diusahakan. Apabila nilai keuntungan sosial lebih besar dari nol berarti pada kondisi pasar persaingan sempurna, aktivitas pengusahaan komoditas tersebut menguntungkan secara ekonomi sehingga layak untuk dikembangkan. Matriks PAM ini juga dapat mengukur keunggulan komparatif dan kompetitif dari usahatani bawang merah. Indikator yang digunakan dalam menentukan dayasaing usahatani bawang merah dalam penelitian ini menggunakan pendekatan keunggulan kompetitif dan komparatif. Menurut Akhtar et al. (2009) dan Boossabong dan Taylor (2009) keunggulan kompetitif memasukkan distorsi pasar (harga pasar) sedangkan keunggulan komparatif menggunakan asumsi pasar tidak terdistorsi (harga equilibrium). Keunggulan kompetitif diukur dengan menggunakan indikator nilai Private Cost Ratio (PCR) (Tabel 1). Sementara itu, keunggulan komparatif diukur dengan menggunakan indikator nilai Domestic Resource Cost Ratio (DRCR) (Tabel 1). Keunggulan kompetitif menunjukkan sejauh mana usahatani bawang merah tersebut mampu membiayai faktor domestiknya pada harga privat atau aktual. Semakin kecil nilai PCR berarti komoditas tersebut semakin kompetitif. Keunggulan kompetitif merupakan dasar kesuksesan dalam pasar lokal dan pasar internasional (Ivan et al., 2011). Keunggulan komparatif mencerminkan efisiensi dalam penggunaan sumberdaya domestik, atau sejauh mana sumberdaya domestik dapat dihemat untuk menghasilkan satu satuan devisa (Sahinli, 2012). Semakin kecil nilai DRCR maka komoditas tersebut semakin memiliki keunggulan komparatif. Penelitian mengenai dayasaing dengan menggunakan metode PAM sudah banyak dilakukan seperti Rachman et al. (2004), Tinaprilla (2008), Zakaria et al. (2010), Adegbite et al. (2014), dan Kapaj et al. (2010). 
J. Hort. Indonesia 8(2): 128-135. Agustus 2017.

Tabel 1. Policy Analysis Matrix (PAM)

\begin{tabular}{lcccc}
\hline \multirow{2}{*}{ Uraian } & \multirow{2}{*}{ Penerimaan } & \multicolumn{2}{c}{ Biaya } & \multirow{2}{*}{ Keuntungan } \\
\cline { 3 - 4 } & & Tradable & Non-Tradable & \\
\hline Nilai Privat & $\mathrm{A}$ & $\mathrm{B}$ & $\mathrm{C}$ & $\mathrm{D}$ \\
Nilai Sosial & $\mathrm{E}$ & $\mathrm{F}$ & $\mathrm{G}$ & $\mathrm{H}$ \\
\hline
\end{tabular}

Sumber: Monke dan pearson (1989)

Keterangan:

1. Keuntungan Privat

2. Keutungan Sosial

$: \mathrm{D}=\mathrm{A}-(\mathrm{B}+\mathrm{C})$

3. Rasio Biaya Privat

$: \mathrm{H}=\mathrm{E}-(\mathrm{F}+\mathrm{G})$

4. Rasio Biaya Sumberdaya Domestik $: D R C R=G /(E-F)$

Penelitian ini akan menganalisis dayasaing usahatani bawang merah dengan menggunakan PAM. Analisis PAM di lokasi penelitian akan dibagi menjadi tiga musim tanam yaitu musim hujan, musim kemarau I, dan musim kemarau II. Hasil analisis PAM di lokasi penelitian akan dibandingkan terkait dengan bagaimana dayasaing usahatani bawang merah di setiap musim. Hasil analisis PAM ini dapat digunakan untuk mengidentifikasi apakah petani bawang merah memiliki dayasaing di ketiga musim tersebut. Adapun tahap analisis dengan metode PAM ini adalah sebagai berikut: Tahapan penyusunan tabel PAM ialah (1) penentuan komponen fisik untuk faktor input dan output secara lengkap, (2) pemisahan seluruh biaya ke dalam komponen domestik dan asing, (3) penentuan harga finansil (privat) dan penaksiran harga bayangan (ekonomi), dan (4) tabulasi dan analisis indikator-indikator yang dihasilkan Tabel PAM.

\section{HASIL DAN PEMBAHASAN}

\section{Keuntungan Privat dan Sosial Komoditas Bawang Merah}

Keuntungan privat usahatani bawang merah mengukur tingkat keuntungan berdasarkan harga input dan ouput secara aktual. Keuntungan sosial adalah keuntungan yang dihitung berdasarkan harga sosial atau bayangan. Jika dibandingkan besaran antara keuntungan privat dan keuntungan sosial yang diterima oleh petani bawang merah di Kabupaten Majalengka, maka keuntungan privat usahatani bawang merah lebih besar dibanding keuntungan sosial (Tabel 2). Hal ini menyatakan bahwa usahatani bawang merah di
Kabupaten Majalengka lebih menguntungkan pada saat adanya kebijakan pemerintah dibanding tanpa adanya kebijakan pemerintah. Kebijakan pemerintah pada input dan output bawang merah secara simultan masih memberikan insentif bagi petani bawang merah sehingga keuntungan privat yang diperoleh lebih besar dibanding keuntungan sosialnya. Besarnya dampak dari kebijakan tersebut dapat dilihat dari nilai divergensi keuntungan yang dihasilkan bernilai positif.

Dilihat berdasarkan pembagian musim tanam bawang merah di Kabupaten Majalengka pada tahun 2014-2015, penerimaan masing-masing petani bawang merah pada setiap musim tanam berbeda-beda sesuai dengan hasil produksi yang diperoleh dan harga yang diterima. Penerimaan privat usahatani bawang merah tertinggi dicapai pada musim hujan yaitu sebesar Rp $40 \quad 467$ 414.09/ha. Besarnya penerimaan yang diperoleh petani bawang merah pada musim hujan ini disebabkan oleh biaya yang dikeluarkan untuk membiayai usahatani bawang merah lebih murah dibandingkan dengan biaya usahatani bawang merah pada kedua musim lainnya. Khususnya pada biaya pengeluaran untuk upah tenaga kerja. Pada musim hujan skala penyiraman tanaman lebih sedikit dibandingkan pada musim kemarau sehingga kebutuhan akan tenaga kerja lebih kecil yang nantinya dapat menekan biaya penggunaan tenaga kerja.

\section{Dayasaing Komoditas Bawang Merah}

Mengukur dayasaing suatu komoditas dalam hal ini berkaitan dengan efisiensi penggunaan sumberdaya maka digunakan dua pendekatan antara lain keunggulan komparatif dan keunggulan kompetitif. Indikator yang 
digunakan untuk mengukur keunggulan komparatif ialah rasio biaya sumberdaya domestik (DRCR), nilai DRCR menunjukkan jumlah sumberdaya domestik yang dapat dihemat untuk menghasilkan satu satuan devisa. Semakin kecil nilai DRCR maka komoditas tersebut semakin memiliki keunggulan komparatif. Untuk mengukur keunggulan kompetitif digunakan indikator rasio biaya privat (PCR), nilai PCR menunjukkan kemampuan sistem komoditas untuk membayar biaya domestik pada harga privat atau aktualnya (Master dan Winter-Nelson, 1995).

Usahatani bawang merah di Kabupaten Majalengka tidak memiliki dayasaing komparatif. Hal ini ditunjukkan dengan nilai DRCR lebih dari 1 sebesar 2.14, yang artinya sistem komoditas tidak mampu berjalan tanpa adanya kebijakan pemerintah yang mendukung usahatani bawang merah baik dari segi input maupun output. Keunggulan komparatif usahatani bawang merah di Kabupaten Majalengka tidak dapat dicapai karena untuk menghasilkan satu unit satuan nilai tambah output diperlukan input non tradable 2.14 satuan. Disamping itu, sebesar 2.14 satuan input non tradable diperlukan untuk menghemat satu satuan devisa pada harga sosial. Dari kajian yang sama, Fatori (2015) juga menunjukkan bahwa usahatani bawang merah di Kabupaten Tegal, Cirebon dan Brebes juga tidak memiliki keunggulan komparatif karena memiliki nilai DRCR lebih besar dari 1 . Hal ini menunjukkan bahwa petani bawang merah di ketiga lokasi tersebut tidak efisien dalam menggunakan sumberdaya domestik.

Berdasarkan Analisis PAM untuk setiap musim (Tabel 3), secara keseluruhan petani bawang merah di ketiga musim tidak memiliki keunggulan komparatif baik pada musim hujan, musim kemarau I ataupun musim kemarau II. Sementara itu, hasil analisis Rachman et al. (2004) melaporkan bahwa di Kabupaten Majalengka pada musim kemarau I dan musim kemarau II justru memiliki keunggulan komparatif dengan nilai DRCR masing-masing sebesar 0.71 dan 0.54 . Penyebab lemahnya keunggulan komparatif pada usahatani bawang merah adalah penggunaan input usahatani yang belum tepat dan tingginya biaya produksi yang dikeluarkan oleh petani di dalam usahataninya.

Tabel 2. Keuntungan privat dan keuntungan sosial usahatani bawang merah di Kabupaten Majalengka pada musim tanam tahun 2014-2015

\begin{tabular}{|c|c|c|c|c|c|}
\hline & \multirow{2}{*}{$\begin{array}{l}\text { Penerimaan } \\
(\mathrm{Rp} / \mathrm{Ha})\end{array}$} & \multicolumn{3}{|c|}{ Biaya (Rp/Ha) } & \multirow{2}{*}{$\begin{array}{c}\text { Keuntungan } \\
(\mathrm{Rp} / \mathrm{Ha})\end{array}$} \\
\hline & & Tradable & Non Tradable & Total & \\
\hline \multicolumn{6}{|l|}{ 1. $\mathrm{MH}$} \\
\hline Privat & 11016 & 11965825.93 & 57729265.12 & 69695091.04 & 40467414.09 \\
\hline Sosial & 013.22 & 12123897.03 & 36276304.66 & 48400201.69 & -16870188.46 \\
\hline Diverg & 78632491.90 & -158071.10 & 21452960.45 & 21294889.36 & 57337602.55 \\
\hline \multicolumn{6}{|l|}{ 2. MK I } \\
\hline Privat & 11385 & 12672672.00 & 76353 & 89026097.47 & 443.78 \\
\hline Sosial & 33998304.90 & 12969685.99 & 54241100.17 & 67210786.16 & -33 212481.27 \\
\hline Divergens & 79853236.35 & -297013.99 & 22112325.30 & 21815311.31 & 58037925.04 \\
\hline \multicolumn{6}{|l|}{ 3. MK II } \\
\hline Privat & 139152702.09 & 14690338.27 & 104506411.12 & 119196749.40 & 19955952.69 \\
\hline Sosial & 57573644.37 & 14846090.38 & 73877071.43 & 88723161.81 & -31149517.44 \\
\hline Divergensi & 81579057.72 & -155752.11 & 30629339.69 & 30437587.58 & 51105470.13 \\
\hline
\end{tabular}

Tabel 3. Keunggulan kompetitif dan komparatif usahatani bawang merah di Kabupaten majalengka per musim tanam tahun 2014-2015

\begin{tabular}{|c|c|c|}
\hline \multirow{2}{*}{ Lokasi } & \multicolumn{2}{|c|}{ Indikator Dayasaing } \\
\hline & PCR & DRCR \\
\hline Kabupaten Majalengka & 0.72 & 2.14 \\
\hline - Musim Hujan & 0.59 & 1.87 \\
\hline - $\quad$ Musim Kemarau I & 0.75 & 2.58 \\
\hline - $\quad$ Musim Kemarau II & 0.84 & 1.73 \\
\hline
\end{tabular}


Beberapa penggunaan input yang belum tepat ini terjadi pada penggunaan sarana produksi pertanian, seperti penggunaan benih, pupuk dan pestisida. Petani bawang merah pada lokasi penelitian ini sebagian besar menggunakan benih yang dibeli di pasar yang pada umumnya berasal dari Jawa, Brebes khususnya atau berasal dari hasil panen sebelumnya dengan cara menyimpan hasil panen tersebut selama 2 sampai 3 bulan. Penggunaan umbi bibit hasil panen sebelumnya menurut Triharyanto et al. (2012) mempunyai banyak kelemahan, karena kualitasnya semakin menurun di antaranya karena infeksi virus. Virus yang umumnya menyerang tanaman bawang merah ada tiga macam yaitu onion yellow dwarf virus (OYDV), leek yellow stripe virus (LYSV) dan shallot latent virus (SLV) (Dovas et al., 2001). Hal ini didukung dengan hasil penelitian yang dilakukan oleh Gunaeni et al. (2011) yang melaporkan bahwa varietas bawang merah asal Jawa Barat dan Jawa Tengah terinfeksi virus OYDV dan LYSV. Selain itu, di lokasi penelitian penggunaan pupuk kimia dan pestisida berlebih dapat menyebabkan menurunnya kesuburan lahan karena lahan sudah jenuh dan tidak diimbangi dengan penggunaan pupuk organik. Las et al. (2006) menyatakan bahwa penggunaan pupuk kimia yang terlalu tinggi dapat memberikan dampak negatif terhadap sumber daya air baik air tanah maupun air irigasi. Novotny et al. (2010) melaporkan dalam penelitiannya dampak penggunaan pupuk kimia terhadap kondisi lingkungan di empat negara yakni China, India, Thailand dan Philipina menunjukkan banyak kandungan nitrogen yang terbawa ke saluran irigasi khususnya di negara China. Tingginya serangan Organisme Pengganggu Tanaman (OPT) dapat membuat petani menjadi lebih sering untuk melakukan penyemprotan. Frekuensi penyemprotan pestisida yang sangat intensif dapat mencapai 15-25 kali per musim tanam ini sejalan dengan penelitian yang dilakukan oleh Dinakaran et al. (2013) yang melaporkan petani di India melakukan penyemprotan menggunakan pestisida setiap 2 sampai 3 hari sekali dalam merawat tanaman bawang tanpa mempertimbangkan tingkat serangan OPT.

Faktor lain yang menyebabkan lemahnya keunggulan komparatif bawang merah di Kabupaten Majalengka ialah tingginya biaya produksi. Hal ini senada dengan penelitian yang dilakukan oleh Rosyadi dan Purnomo (2014) yang menyatakan bahwa usahatani bawang merah tidak efisien secara biaya. Proporsi pengeluaran benih bawang merah cukup tinggi yaitu berkisar antara 23.85 sampai 28.84 persen dari total biaya usahatani bawang merah, dengan rata-rata harga beli yang didapat petani sebesar Rp 20400 sampai Rp 23366.67 per kilogramnya, dengan rata-rata kebutuhan benih setiap musim tanam di Kabupaten Majalengka berkisar antara 1 075.31 sampai $1308.62 \mathrm{~kg} \mathrm{ha}{ }^{-1}$. Selain pengeluaran untuk benih, pengeluaran untuk tenaga kerja juga menempati proporsi biaya tertinggi di dalam usahatani bawang merah di Kabupaten Majalengka, yaitu berkisar antara 32.72 sampai 47.51 persen. Kebutuhan tenaga kerja yang lebih banyak ini terdapat pada kegiatan pengolahan tanah (33\%), penyemprotan $(21 \%)$ dan penyiraman $(20 \%)$. Hal yang berbeda ditunjukkan oleh hasil penelitian yang dilakukan oleh Asih (2009) yaitu pengeluaran terbesar terjadi pada penggunaan input benih mencapai 64.08 persen terhadap total biaya, sedangkan biaya untuk tenaga kerja menempati posisi terbesar kedua sebesar 29.74 persen terhadap total biaya.

Pendekatan untuk mengukur dayasaing suatu komoditas selain keunggulan komparatif adalah keunggulan kompetitif. Keunggulan kompetitif diukur dengan menggunakan indikator PCR. Nilai PCR pada usahatani bawang merah di Kabupaten Majalengka kurang dari 1 yaitu 0.72 , yang artinya untuk mendapatkan nilai tambah output usahatani bawang merah sebesar satu satuan diperlukan tambahan biaya input non tradable kurang dari satu satuan yaitu 0.72 . Keunggulan kompetitif terbesar dicapai pada musim hujan dengan nilai PCR sebesar 0.59. Jika dibandingkan dengan kedua musim lainnya, musim hujan lebih memiliki dayasaing karena keunggulan kompetitifnya yang lebih besar. Hal tersebut berbeda dengan hasil analisis Rachman et al. (2004) yang menyatakan usahatani bawang merah di Kabupaten Majalengka pada musim kemarau II lebih berdayasaing ditunjukkan dengan nilai PCR yang lebih kecil dari 1 yaitu sebesar 0.31 . 


\section{KESIMPULAN}

Usahatani bawang merah di Kabupaten Majalengka menguntungkan secara privat tetapi tidak menguntungkan secara sosial. Hal ini menunjukkan kebijakan pemerintah terkait dengan usahatani bawang merah yang diterapkan saat ini dapat memberikan insentif bagi petani bawang merah di Kabupaten Majalengka. Usahatani bawang merah di Kabupaten Majalengka menunjukkan dayasaing yang lemah. Bawang merah untuk ketiga musim di Kabupaten Majalengka masih memiliki keunggulan kompetitif namun tidak memiliki keunggulan komparatif.

\section{SARAN}

Berdasarkan hasil analisis dan kesimpulan yang didapat maka dirumuskan beberapa saran implikasi kebijakan, yaitu: Untuk meningkatkan dayasaing komoditas bawang merah di Kabupaten Majalengka, pelaku usahatani harus menggunakan benih bawang merah yang bermutu dalam artian memiliki produktivitas yang tinggi, menggunakan pupuk dan pestisida sesuai dengan kebutuhan berdasarkan dosis yang dianjurkan serta perbaikan dalam teknik budidaya sesuai prosedur operasional baku.

\section{DAFTAR PUSTAKA}

Adegbite, O., O. Oni, I. Adeoye. 2014. Competitiveness of pineapple production in Osun State, Nigeria. J. Economics and Sustainable Development. 5(2): 205-214.

Akhtar, W., M. Sharif, H. Shah. 2009. Competitiveness of Paskitani fruits in the world market. The Lahore Journal of Economics. 14(2): 125-133.

Apriani, L.N. 2011. Analisis efisiensi teknis dan pendapatan usahatani bawang merah (studi kasus: Desa Sukasari Kaler, Kecamatan Argapura, Kabupaten Majalengka, Jawa Barat). [Tesis]. Bogor (ID): Institut Pertanian Bogor
Asih, D.N. 2009. Analisis karakteristik dan tingkat pendapatan usahatani bawang merah di Sulawesi Tengah. J. Agroland. 16(1): 53-59.

Boossabong, P., M.F. Taylor. 2009. Impact of trade liberalization on the agricultural sector and adjustment policy: the case of shallot plantations in northeastern Thailand. Kasetsart J. Soc. Sci. 30: 323337.

[BPS] Badan Pusat Statistik. 2014. Perkembangan indeks harga konsumen/ inflasi. Berita Resmi Statistik. Jakarta.

Dinakaran, D., G. Gajendran, S. Mohankumar, G. Karthikeyan, S. Thiruvudainambi, El. Jonathan, R. Samiyappan, E.G Pfeiffer, G.W. Norton, S. Miller, R. Mumappa. 2013. Evaluation of integrated pest and disease management module for shallots in Tamil Nadu, India: a farmer participatory approach. J. Integ. Pest Mngmt. 4(2): 2013.

Dovas, C., E. Hatziloukas, R. Salomon, E. Barg, Y. Shiboleth, N. Katis. 2001. Indcidence of viruses infecting Allium spp. In Greece. European Journal of Plant Pathology. 107: 677-684.

Fatori, H. 2015. Dayasaing bawang merah di wilayah sentra produksi di Indonesia. [Tesis]. Bogor (ID): Institut Pertanian Bogor.

Fauziah, R., A.D. Susila, E. Sulistiono. 2016. Budidaya bawang merah (Allium ascalonicum $\mathrm{L}$ ) pada lahan kering pada berbagai model dan frekuensi irigasi. J. Hort. Indonesia. 7(1): 1-8.

Gunaeni, N., A.W. Wulandari, A.S. Duriat, A. Muharram. 2011. Insiden penyakit virus tular umbi pada tiga belas varietas bawang merah asal Jawa Barat dan Jawa Tengah. J. Horti. 21(2): 164-172.

Kapaj, A.M., I. Kapaj, C.C. Halbrendt, O. Totojani. 2010. Assessing the comparative advantage of Albanian olive oil production. International Food 
and Agribusiness Management Review. 13(1): 15-25.

[Kementan] Kementerian Pertanian. 2015. Statistik Perdagangan Luar Negeri (Ekspor dan Impor). Jakarta (ID): Departemen Pertanian.

Kennedy, P. Lynn., R. Wess Harisson., Mario A. Piedra. 1998. Analyzing agribusiness competiveness: the case of the United States sugar industry. International food and Agribusiness Management Review. 1(2): 245-257.

Las, I., K. Subagyono, A.P. Setyanto. 2006. Isu dan pengelolaan lingkungan dalam revitalisasi pertanian. Jurnal Litbang Pertanian. 25(3): 2006.

Novotny, X. Wang, A.J. Englade, D. Bedoya, L. Promakasikorn, R. Tirado. 2010. Comparative assessment of pollution by the use of industrial agricultural fertilizers in four rapidly developing asian countries. Environmental Dev Sustain. 12: 491-509.

Rachman, H.P.S., Supriyati, Saptana, B. Rachman. 2004. Efisiensi dan dayasaing usahatani hortikultura. Bogor, Indonesia. Bogor (ID). PSEKP, hlm 5082.
Rosyadi, I., D. Purnomo. 2014. Profitabilitas dan efisiensi usahatani bawang merah. Jurnal Ekonomi Pembangunan. 15(2): 117-127.

Sahinli, M.A. 2012. Comparative advantage of agriculture sector between Turkey and European union. African Journal of Agricultural Research. 8(10): 884-895.

Tinaprilla, N. 2008. Analisis daya saing dan kebijakan pemerintah pada usahatani cabe merah (kasus Kecamatan Ciwidey Kabupaten Bandung dan Kecamatan Lembang Kabupaten Bandung Barat). J. Agribisnis dan Ekonomi Pertanian. 2(2): 39-64.

Triharyanto, E., Samanhudi, B. Pujiasmanto, D. Purnomo. 2013. Kajian pembibitan dan budidaya bawang merah (Allium ascalonicum $\mathrm{L}$ ) melalui biji botani (True Shallot Seed). http://lppm.uns.ac.id/ kinerja/files/pemakalah/lppm-pemakalah2012-1308201395456.pdf. [28 April 2016].

Zakaria, A.K., W.K. Sejati, R. Kustiari. 2010. Analisis daya saing komoditas kedelai menurut agro ekosistem: kasus di tiga provinsi di Indonesia. J. Agro Ekonomi. 28(1): 21-37. 